\title{
HERALD CO. v. SEAWELL: \\ A NEW CORPORATE SOCIAL RESPONSIBILITY?
}

The law has not encouraged acts of corporate social responsibility. The long-accepted holding of Dodge v. Ford Motor Co." that "[a] business corporation is organized and carried on primarily for the profit of stockholders" has set the tone of decisions since 1919. This notion is so firmly settled that one legal scholar has noted that to suggest corporate management has the right to forego substantial marginal profits in the name of "social responsibility" is to propose "a new and radically altered form of economy."2

There is, however, growing, widespread and articulate pressure on corporate management to consider the interests of constituencies other than stockholders, specifically employees and the public, when making policy decisions. ${ }^{3}$ As a result, courts must confront the question whether acts of corporate social responsibility, done in the public interest, should be approved if challenged by stockholder suits. In Herald Co. v. Seawell ${ }^{4}$ the Court of Appeals for the Tenth Circuit recently stated that the discretionary power vested in a board of directors includes the power to act in the public interest at potential financial cost to the stockholders.

\section{The Herald Co. Decision}

The Herald Co. court suggested in broad dicta that directors may cause their corporation to purchase its own shares to prevent an outsider from taking control of the corporation, if the board fears that the outsider will not operate the corporation in the best interests of the public. The case marks the first time a court has suggested that a corporation can block a takeover bid by purchasing its own shares for any reason other than to protect business interests. It is the first judicial assertion that corporate management has an obligation to operate its business in a socially responsible manner. ${ }^{5}$

1204 Mich. 459, 507, 170 N.W. 668, 684 (1919).

2 Hetherington, Fact and Legal Theory: Shareholders, Managers and Corporate Responsibility, 21 StAN. L. Rev. 248, 279-80 (1969), citing Manne, Book Review, 24 U. CHII. L. Rev. 194, 198 (1956). See H. MaNNe \& H. Warlich, The Moders Corporation and Soctal ResponsibItITy 1-37, 65-71 (1972). But of. R. EeIs, Corporatton GIVING IN A FREE SOCIETY passim (1956).

3 Corporate Power IN America passim (R. Nader \& M. Green eds. 1972); Blumberg, Goldston \& Gibson, Corporate Social Responsibility Panel: The Corstituencies of the Corporation and the Role of the Institutional Investor, 28 Bus. LAw. 177 (1972); Hershman, An Overview, 28 Bus. LAw. 1, 4-7 (1972); see Albrook, Business Wrestles with its Social Conscience, Fortune, Aug. 1968, at 89.

4472 F.2d 1081 (10th Cir. 1972).

5 Blumberg, Corporate Responsibility and the Social Crisis, 50 B.U.I. REv. 157, 174 (1970). See also Gower, Corporate Control: The Battle for the Berkeley, 68 HARv. L. 
Herald Co. arose out of an unsuccessful attempt by Samuel Newhouse, owner of one of the nation's largest newspaper chains, to acquire control of the Denver Post. In 1960, when Newhouse first resolved to take over the newspaper, the stock of The Denver Post, Inc., was held by Helen G. Bonfils and May Bonfils Stanton, daughters of one of the paper's founders, and by several trusts. Newhouse, through a wholly-owned corporation, purchased the shares owned by Ms. Stanton. At the time of the purchase, this block of shares represented sixteen percent of the outstanding stock of the Post. Shortly thereafter the Post, pursuant to a unanimous resolution of its directors, acquired a block of stock, then comprising twenty-one percent of the outstanding shares, from one of the trusts. The Post intended to use these shares, supplemented by others donated by Ms. Bonfils, to establish an employee stock ownership plan designed to preserve and foster good labor relations. The directors were aware that the establishment of the plan "would eventually lock control of the corporation in the employees and eliminate the possibility of any outsider gaining stock control of the corporation." 8

The 1960 securities purchase frustrated Newhouse's bid for control. In 1966, Ms. Bonfils acquired the shares held by another of the trusts, thereby gaining direct or indirect control of a majority interest in the Post and extinguishing any hope Newhouse may have retained of acquiring control.

Two years later, Newhouse brought a derivative suit against the directors and officers of the Post, charging them with misconduct, breach of trust and misuse of corporate assets. Although other issues were litigated, the purchase of shares for the employee stock ownership plan was the primary subject of this appeal. ${ }^{7}$ The Tenth Circuit,

Rev. 1176, 1192 (1955). But see L. Gower, The Principles of Modern Company Law 9-11 (3d ed. 1969) (regarding earlier expressed view as anachronistic). A. BERLE, THE 20te Century Capitaisst Revolutron 169 (1954) states:

Twenty years ago, the writer had a controversy with the late Professor E. Merrick Dodd, of Harvard Law School, the writer holding that corporate powers were powers in trust for shareholders while Professor Dodd argued that these powers were held in trust for the entire community. The argument has been settled (at least for the time being) squarely in favor of Professor Dodd's contention.

Dodd's theory is presented in Dodd, For Whom Are Corporate Managers Trustees?, 45 HARv. L. REv. 1145 (1932). But cf. Abrams v. Allen, 297 N.Y. 52, 74 N.E.2d 305 (1947) (rights of employees).

6472 F.2d at 1084. See Blumberg, Goldston \& Gibson, supra note 3, at 188:

The influence [of an employee trust fund] on management will depend on the procedure for voting the shares held by the trust. In the typical case, where the shares are voted by trustees appointed (and often subject to removal) by the Board of Directors, the employee trust fund-far from increasing the relative power of employees-becomes a device for further strengthening the entrenched position of management through the creation of captive votes.

7 The trial court found that the defendant directors misused substantial corporate assets by acquiring the block of stock used for the employee stock ownership plan at an inflated price. The court characterized the purchase as one motivated purely by a desire to retain and lock up control of the corporation, and applied a test under which a corporation would never have the right to purchase its own shares to prevent a take- 
in a lengthy opinion, held that because the directors had genuinely hoped to improve labor relations by creating the employee stock ownership plan, their conduct was not objectionable, despite the directors' awareness that the plan would forever prevent control of the Post from falling into the hands of outsiders. Furthermore, the court held that because Newhouse had waited eight years before bringing suit, recovery was barred by the statute of limitations, laches and the doctrine of acquiescence.

This Comment will focus upon the court's dictum that the directors' actions were proper in order to prevent the corporation from falling into the hands of an outsider; one who would not continue certain policies believed vital to the welfare of the employees and the public, although marginally less profitable for the corporation. ${ }^{8}$ The court asserted that the editorial policies and community action programs of the Post under the incumbent management "are only a few examples of the officers' and directors' placing the public needs and good above the desire for profit, and, as we have indicated, are wholly justified."

Previous courts have held that directors may cause their corporation to purchase its own shares only as a defense to a clear threat to the business interests of the corporation. Although many courts and almost all state legislatures have decided that corporations may recognize social obligations by donating reasonable amounts to worthy causes, ${ }^{10}$ no previous court has suggested that these obligations may be recognized in the operational and policy decisions of the firm.

\section{The Right of a Corporation to Purchase ITS OWN SHARES}

To place the expansive dicta of Herald Co. in proper perspective, it is useful to note the two basic approaches which courts have taken in resolving conflicts that emerge when a corporation acquires its own shares to avert a change in control. The Massachusetts Supreme Judi-

over. The district court opinion also asserted that "it is not a legitimate corporate activity to give away the resources of the corporation, no matter how worthy or needy the donee may be . ..." Herald Co. v. Bonfils, 315 F. Supp. 497, 501-03 (D. Colo. 1972), noted 15 ST. Lours U.L.J. 651 (1971) (criticizing the decision and suggesting reversal).

8 See H. Manne \& H. Wallich, supra note 2, at 4:

Any working definition of the idea of corporate social responsibility must begin with the idea that the expenditure or activity be one for which the marginal returns to the corporation are less than the returns available from some alternative expenditure. That is not to say that the company must in absolute terms lose money but simply that it makes less money than would otherwise be the case.

In one analysis of the demand for corporate social responsibility, a leading corporate attorney, G.D. Gibson, has summarized the impact on corporate goal setting thus: "In this manner the fundamental objective of corporate management becomes not profit maximization, but profit optimization." Blumberg, Goldston \& Gibson, supra note 3, at 209.

9472 F.2d at 1097 (10th Cir. 1972).

10 See sources cited \& text accompanying notes 30-31 infra. 
cial Court flatly condemned the practice. ${ }^{11}$ The directors of a corporation, that court held in a leading case, "cannot take advantage of their official position to manipulate the issue and purchase of shares of the stock of the corporation in order to secure for themselves control of the corporation ...."12 The Delaware courts have developed a more flexible view, ruling that such purchases are proper where the directors are motivated by a desire to "eliminat[e] what appears to them a clear threat to the future of their business." "13

The jurisdictions that follow the Delaware rule have approved purchases by a corporation of its own shares to prevent the election of new directors, where the existing board feared that the new directors would sacrifice an established mode of doing business to quick profits, to the future detriment of the corporation $;^{14}$ adopt sales practices that would be unsatisfactory for the corporation's product line; ${ }^{15}$ order a quick and untimely liquidation; ${ }^{10}$ manipulate the affairs of the company for their own profit; ${ }^{17}$ or remove key personnel. ${ }^{18}$ On the other hand, courts have condemned this practice where the incumbent directors wished to continue a policy of paying themselves unjustifiably high salaries, ${ }^{19}$ or merely to guarantee their continued tenure as officers of the corporation. ${ }^{20}$ The burden of proof always rests on the incumbent directors to establish that their motive in entering into the defensive course of conduct was to protect the corporation and not merely to further their own ends. ${ }^{21}$ The court in Herald Co. chose to apply

11 Andersen v. Albert \& J.M. Anderson Mfg. Co., 325 Mass. 343, 90 N.E.2d 541 (1950); see Elliot v. Baker, 194 Mass. 518, 80 N.E. 450 (1907).

12325 Mass. at 346,90 N.E.2d at 544.

13 Kors v. Carey, 39 Del. Ch. 47, 55, 158 A.2d 136, 141 (Ch. 1960), noted, 70 YaLE L.J. 308 (1960); cf. Cheff v. Mathes, 41 Del. Ch. 494, 503-04, 199 A.2d 548, 554 (Sup. $\mathrm{Ct}$. 1964). The line between the Massachusetts rule and the Delaware rule may not be quite this distinct. Although 1 authority maintains that the 2 courts are following different rules of law, Israels, Corporate Purchase of Its own Shares-Are There New Overtones?, 50 CORNELI L.Q. 620 (1965), the First Circuit in McPhail v. L.S. Starrett Co., 257 F.2d 388 (1st Cir. 1958), found the holding in Andersen applicable to a case (decided under a liberal interpretation of Massachusetts law) where the directors' pur: pose was to prevent the accession to the board of a "raider" who only sought to become a director so that he might manipulate the affairs of the corporation for his personal profit.

Although in $M c P$ Pail the challenged manipulation of the company's stock was the sale of authorized but unissued shares, rather than the purchase of outstanding shares, the court would probably have applied the same interpretation of the Andersen rule in either case.

14 Kors v. Carey, 39 Del. Ch. 47, 55, 158 A.2d 136, 141 (Ch. 1960).

15 Cheff v. Mathes, 41 Del. Ch. 494, 199 A.2d 138 (Sup. Ct. 1964).

$16 I d$.

17 McPhail v. L.S. Starrett Co., 257 F.2d 388 (1st Cir. 1958).

18 Hendricks v. Mill Eng'r \& Supply Co., 68 Wash. 2d 490, 492, 413 P.2d 811, 813 (1966). (1943).

19 Kullgren v. Navy Gas \& Supply Co., 110 Colo. 454, 459, 135 P.2d 1007, 1009-10

20 Bennett v. Propp, 41 Del. Ch. 14, 20, 187 A.2d 405, 408 (Sup. Ct. 1962).

21 Cheff v. Mathes, 41 Del. Ch. 494, 504-05, 199 A.2d 548, 554 (Ch. 1964); Bennett v. Propp, 41 Del. Ch. 14, 22, 187 A.2d 405, 409 (Sup. Ct. 1962). 
the more liberal Delaware approach to the activities of the directors of a Colorado corporation. ${ }^{22}$ Under the Delaware rule the court was obligated to determine if Newhouse's bid to take control represented a clear threat to the future of the Post. There was evidence of such a threat; the papers owned by Newhouse had a reputation within the newspaper industry of poor relations with their employees. ${ }^{23}$ In light of the effect of bad labor relations on the economic well-being of newspapers, the Post could have regarded the threat presented by Newhouse to its satisfactory labor relations as a threat to the future of the newspaper. ${ }^{24}$ The court could have categorized the purchase of stock as properly within the Post's "business interest" of self-protection.

But the court was not content to test the directors' actions solely on this narrow basis. Rather it emphasized the directors' fear that Newhouse would discontinue certain editorial and community service policies they believed were beneficial to the public. ${ }^{25}$ If these policies, by serving the public, increased circulation or otherwise improved the profit outlook of the corporation, then Newhouse's predisposition to do away with them would clearly have represented a threat to the future of the corporation. Defensive acts would have been justified to eliminate the threat. The policies involved here, however, did not improve the Post's profit picture:

Testimony [was] undisputed ... that the Post could have made more profits if it had cut down on the quality of its newspaper product, eliminated some of the editorial employ-

22 In Kullgren v. Navy Gas \& Supply Co., 110 Colo. 454, 461, 135 P.2d 1007, 1010 (1943), the Colorado Supreme Court held that "[c]orporate directors cannot manipulate the property, of which they have control ... primarily with the intent to secure a majority of the stock or of directors in any particular interest." If this holding can be taken literally, cf. note 13 supra, the Herald Co. court by applying the Delaware rule violated the doctrine of Erie R.R. Co. v. Tompkins, 304 U.S. 64 (1938). In Kullgren, however, the Colorado court found that the directors had been misusing their offices by paying themselves high salaries and at the same time declaring no dividends. Perhaps the Tenth Circuit assumed that the Colorado bench would not apply the Kullgren holding to a case in which the directors were trying in good faith to protect the corporation. However, Kullgren was not even cited by the Herald $\mathrm{Co}$. court.

23472 F.2d at 1092.

24 For a general discussion of the fiduciary responsibility of boards of directors to employees, and an argument for greater attention to employee concerns, see Blumberg, Goldston \& Gibson, supra note 3, at 177. Cf. Mahoney, What Happened at Endicott Johnson After the Band Stopped Playing, Fortune, Sept. 1962, at 126 (large group of loyal employees purchased shares to help defend local management from takeover attempt by outsiders).

... [T] [Te English have become increasingly concerned with asset stripping: or the takeover of firms, with the intent to reduce the scale of operations and the number of employees and to achieve recovery of the bulk of the purchase price through the sale of the redundant assets. This practice has become increasingly controversial because of the adverse impact on employees.

Blumberg, Goldston \& Gibson, supra note 3, at 193. But see Parke v. Daily News, Itd., [1962] 3 W.I.R. 566 (plan to make a gift of a large part of bought-out company's funds in order to benefit its employees was ultra vires and not taken in the interests of the shareholders).

28472 F.2d at 1097. 
ees, and ceased promotion of many programs the directors sincerely felt were beneficial to the public in the geographic region the newspaper served. ${ }^{26}$

Recognizing this fact, the significant question confronted in this case is: does the possibility that a new board of directors would discontinue unprofitable but publicly beneficial policies entitle the directors to react in defense of the corporation in the same manner as if the threat were to the corporation's financial well-being? As long as the directors' single fiduciary responsibility before the law is owed to the shareholders, ${ }^{27}$ that question must be answered in the negative.

\section{Corporate Social Responsibility: Enforceable Duties and Voluntary ACts of CoRporate Conscience}

The notion that directors have a duty only to shareholders is fading. ${ }^{28}$ Courts have begun to speak in terms of the public obligations of corporations. ${ }^{29}$ State legislatures have fostered this notion by enacting statutes enabling corporations to donate assets to social, educational and scientific causes. ${ }^{30}$

The social responsibilities of corporations may be divided into two types-those that are enforceable and those that are voluntary acts of corporate conscience. The distinction between the two types is that between a duty and a power. Corporate social duties are those that the state enforces directly by the criminal law, or indirectly by allowing private citizens to bring suits in its courts to force compliance or to punish noncompliance. For example, a manufacturer has a duty to produce safe products; a tanner, to use the classic example, not to create a nuisance; a consumer credit agency, not to force upon borrowers unconscionable contracts; a publisher, not to print vilifying lies. These duties are always prior to the director's duty to maximize profits and dominate it.

In the past, courts have found in the area of corporate social

$26 I d$.

27 See, e.g., Hudson v. American Founders Life Ins. Co., 151 Colo. 54, 377 P.2d 391 (1962). Cf. 472 F.2d at 1094-95.

28 See sources cited note 3 supra; see also Rockefeller, Corporate Capacity for Public Responsibility, 28 Bus. Law., Mar. 1973 Special Issue 53.

29 See A.P. Smith Mfg. Co. v. Barlow, 13 N.J. 145, 98 A.2d 581, appeal dismissed, 346 U.S. 861 (1953).

30 For a list of citations to such statutes, see Blumberg, supra note 5, at 208-10. The Colorado statute provides: "Each corporation shall have power: . . . (13) To make donations for the public welfare or for charitable, scientific or educational purposes; and in time of war to make donations in aid of war activities . . .." CoLo. REv. StaT. ANN. § 31-2-1(13) (1963). The Delaware statute is substantially the same, DeL. CODE ANN. tit. 8, \& 122(9) (1953), but adds: "(12) [A corporation may] [t]ransact any lawful business which the corporation's board of directors shall find to be in aid of governmental authority." Id. § 122(12). The New York and New Jersey acts are also similar to Colorado's, but state clearly that a corporation may make donations "irrespective of corporate benefit." N.J. STAT. ANN. 14A:3-4(1) (1969) ; N.Y. BUS. CORP. LAW \& 202 (a) (12) (McKinney 1963). 
responsiveness some power to give corporate assets to social causes. The exact boundaries of this power are vague; the magnitude of corporate gifts and the beneficiaries of corporate largess are left to the discretion of the directors. This power is secondary to the directors' duties to the shareholder. Corporate gifts are limited to an amount deemed reasonable relative to the means of the corporation. ${ }^{31}$

To date the voluntary social responsibilities undertaken by corporations have burdened them only slightly. Although gifts of up to five percent are tax-deductible, ${ }^{32}$ few corporations approach even this limit; the average annual corporate contribution is one percent of pretax income. ${ }^{33}$ This very minor dissipation of corporate assets does not have a substantial impact on the goals of corporate directors or on the day-to-day operations of the firm. Directors substantially maximize profits, fulfilling their primary obligation to the shareholders, despite disbursing sufficient funds to comply with the traditional level of charitable responsiveness demanded by society.

The Tenth Circuit, however, suggested that this view of corporate responsibility is too narrow, asserting:

In this case we have a corporation engaged chiefly in the publication of a large metropolitan newspaper, whose obligation and duty is something more than the making of corporate profits. Its obligation is three-fold: to the stockholders, to the employees, and to the public. ${ }^{34}$

In reaching this result, the court relied upon charitable giving cases concerning the social obligations of corporations. ${ }^{35}$ The court failed, however, to recognize the distinction between social obligations in the disbursement of corporate funds and those in the actual management of the enterprise. The distinction is meaningful; its import should be clearly analyzed.

If the pursuit of social goals in the actual management of the corporation is to be approved, the burden of fashioning checks upon director discretion will increase. Where the corporation's only duty to

31 See A.P. Smith Mfg. Co. v. Barlow, 13 N.J. 145, 154, 98 A.2d 581, 586, appeal dismissed, 346 U.S. 861 (1953). See also Memorial Hosp. Ass'n v. Pacific Grape Prod. Co., 45 Cal. 2d 634, 639, 290 P.2d 481, 484 (1955); Union Pac. R.R. v. Trustees, Inc., 8 Utah 2d 101, 107, 329 P.2d 398, 401 (1958). Blumberg, supra note 5, argues that in addition to being reasonable in amount, the donation must traditionally be reasonably related to the business of the corporation.

32 INT. REv. CODE OF 1954, § 170.

33 Wall St. J., Jan. 11, 1971, at 2, col. 4 (reporting on a study by C.W. Shever \& Co., a New York fund raising firm, based upon the 1966-67 corporate tax returns of 939,846 companies. The most charitable corporations were banks and printing and publishing firms, which gave $2.1 \%$ of their pretax income. Car and truck manufacturers and oil and gas drilling companies were at the other end of the spectrum, giving only $0.3 \%$ and $0.1 \%$ respectively.

34472 F.2d at 1091 (footnote omitted, emphasis added).

35 Id. n.5. 
the public is to give away reasonable sums of money at intervals, it is relatively easy to ascertain, by objective criteria, whether such expenditures are beneficial to the corporation and whether or not the amounts are excessive. But where the corporation asserts that it has included a social-duty factor in decisions made in running the corporation, checks are more difficult to devise. The costs of socially-oriented programs are likely to be buried in the expense accounts of the firm, indistinguishable from expenses incurred in the normal profitmaking activities of the company: for example, inclusion in the cost of a capital asset of the price of emission-control apparatus not required by law. Or the cost of a program could be in lost opportunities, a cost that can never be accurately estimated.

This imprecise accounting for public service and social responsibility as inputs in decisionmaking would greatly increase the difficulty of evaluating managerial performance. ${ }^{36}$ This, in turn, would deprive stock market analysts and investors of objective standards for measuring corporate performance. Therefore, it has been argued that "[a] ssumption by management of diverse social responsibilities would interfere with the fundamental relationship between the enterprise and the investor."37

Recognizing these problems, a new concept of "social accounting," ${ }^{, 38}$ which would measure in objective terms and record in financial statements the costs and benefits associated with voluntary acts of corporate conscience, is necessary. Such a system has not yet been devised and

we cannot expect that by tomorrow we will have ... a magic formula for putting a social-economic bottom line in corporate annual reports. Social accounting is a relatively simple concept to describe, but a terribly difficult task to implement. ${ }^{39}$

Complicating the difficulty of fashioning meaningful and reasonable checks on corporate action in the public interest ${ }^{40}$ is the fact that directors will have control over increasingly large amounts of corporate funds. Recognition of public policy in management decisions tends to be far more expensive than "giveaway" programs. General Motors and Ford gave away $\$ 8$ million and $\$ 9$ million respectively in 1971 ; in the same year they expended $\$ 182$ million and $\$ 120$ million developing automotive emission controls that will meet government

36 See Hetherington, supra note 2 , at $279-81$; but of. H. Manne \& H. Wardich, supra note 2, at 52 ("recognition that the stockholder with a diversified portfolio has a broader range of interests than the maximization of the profits of any one corporation" is a factor favoring corporate social activity).

37 Hetherington, supra note 2 , at 280.

38 Rockefeller, supra note 28, at 55-56; see G. Goyder, The Responsible Comipany 109 (1961) (social audit).

39 Rockefeller, supra note 28 , at 56.

40 See Hetherington, supra note 2, at 280. 
standards. ${ }^{41}$ Although these government-mandated expenditures cannot be considered discretionary, they reflect the order of magnitude involved.

Because "social policy" is an amorphous concept there will be no way to assure that the directors are implementing policies the public truly desires. ${ }^{42}$ It is difficult for shareholders to express to the board their opinions on policies they wish the corporation to undertake. ${ }^{43}$ Directors, seeking to serve the public interest, may be implementing their own personal views. Like directors seeking pecuniary enrichment through the perpetuation of control, directors wishing to orient their firms socially desire to preserve their control to encourage social, economic or ecological changes they, as individuals, believe to be beneficial to society. ${ }^{44}$ It can be argued that because they are causing the corporation to purchase its shares to further their policies, they should be treated the same as directors who wish to retain their positions purely for personal enrichment.

In addition, extending the concept of corporate social responsibility beyond charitable giving to the actual operations of the firm has been criticized as a potential danger to the nation's economic wellbeing. The profit-maximizing model of the capitalist system allocates capital, labor and other resources to the various sectors of the economy in a manner that theoretically assures the maximum satisfaction of consumer desires. Corporate charitable giving works only a minimal disruption on this system. But some economists argue that if, as the Herald Co. court suggests, corporations need not seek maximum profits, fundamental disruptions may occur:

Few trends could so thoroughly undermine the very foundations of our free society as the acceptance by corpo-

41 General Motors Corp. Ann. Rep. 1971 at 19, 22 ; Ford Motor Co. Ann. Rep. 1971 at $16,19$.

42 See M. Friedman, Capitalisar and Freedoar 133-34 (1962); Blumberg, sulpro note 5 , at 176 (footnote omitted):

The older doctrine of 'benefit,' focussing on direct improvement of revenues and thus the position of shareholders (i.e., short-term profit orientation), provided a ready standard for the conduct of the enterprise. Elimination of such a standard properly raises the question of the standard to be substituted. In light of the increasingly powerful role of business institutions, and the imperative need of establishing a legal framework for the control and accountability of the significant sources of power in the society, there is legitimate concern about the potential use of such power and the availability of controls to assure proper accountability.

See also R. EELS, supra note 2, at 49 (1956) (discontent among some with the way foundations and causes they support spend money).

43 See Eisenberg, The Legal Roles of Shareholders antd Management in Modern Corporate Decisionmaking, 57 CALIF. L. REv. 1 (1969); Medical Comm. for Human Rights v. SEC, 432 F.2d 659 (D.C. Cir. 1970), vacated as moot, 404 U.S. 403 (1972); Securities Exchange Act of 1934 \& 14, 15 U.S.C. § 78n (1970); SEC Exchange Act Rule 14a-8(c)(2) (ii), 37 Fed. Reg. 23178 (1972), to be codified at 17 C.F.R. \& 240.14a-8 (c) (2) (ii).

44 H. MANNE \& H. WALIICB, supra note 2, at 8: "The concept of corporate responsibility fiatters businessmen that they are the divine elect ...." 
rate officials of a social responsibility other than to make as much money for their stockholders as possible. This is a fundamentally subversive doctrine. If businessmen do have a social responsibility other than making maximum profits for stockholders, how are they to know what it is? Can selfselected private individuals decide what the social interest is? Can they decide how great a burden they are justified in placing on themselves or their stockholders to serve that social interest? ${ }^{45}$

Other economists believe, however, that the encouragement of corporate social responsibility has the advantage of "shifting from the public to the private sector activities that should be performed with maximum economy rather than maximum bureaucracy. It fits into the design of a pluralistic society seeking a high degree of decentralization." 46 They urge purists to recognize that the "presence of externalities, positive and negative, causes the allocation of resources by the market to deviate from the social optimum." $" 47$

It is not essential here to determine which school of economics is correct; what is significant is to recognize that the bold dicta of Herald Co. could, if applied literally, catalyze a substantial reallocation of corporate resources, causing a marked impact on the economy.

\section{NARROWER INTERPRETATIONS OF Herald Co.}

Despite the reservations just expressed, the result in Herald Co. is less subject to criticism than is the full sweep of the court's language. It is, therefore, worthwhile to seek a reading of the case that will limit the breadth of its impact on corporate law.

\section{A. The Discretion of Nevespaper Directors}

Despite its broad dicta, much of the language of the opinion supports a narrower reading: that director responsibility to the public and employees in operational decisionmaking is necessary and justified only in the newspaper business. ${ }^{48}$ The importance of a vital and responsible "fourth estate" might have been a primary, though unspoken, concern of the court, implicitly balanced against the expansion of unchecked director discretion. Radio and television stations must periodically meet public service standards established by the Federal Communications Commission ${ }^{49}$ and show responsiveness to the public in-

$45 \mathrm{M}$. FrIedMan, supra note 41 , at 133; see Rostow, To Whom and for What Ends Is Corporate Management Responsible?, in The CORPORATION IN MOdERN Socretr 46, 67-69 (E. Mason ed. 1960).

46 H. MANNE \& H. WaLtich, supra note 2 , at 57 .

47 Id. 49.

48472 F.2d at 1094-95.

49 See Anthony, Towards Simplicity and Rationality in Comparative Broadcast Licensing Proceedings, 24 Stan. L. REv. 1 (1971); Fenton, The F.C.C. and the License Renewal Process, 5 SUfFol. U.L. Rev. 389 (1971). 
terest to obtain a right to use the airwaves. The newspaper industry is not similarly regulated. The editorial content of a newspaper is molded only by self-regulation and, in markets served by several newspapers, by the force of competition. For the Herald Co. court to hold that responsiveness to the public and the board policy of setting and protecting quality editorial content was a violation of the directors' fiduciary duty to the stockholders might have opened all responsive newspaper managements in one-paper communities to stockholder pressure for higher profits at the cost of lower-quality news service. Such a holding could have undercut self-regulation within the newspaper industry. The ultimate result of such a decision, if adopted by other circuits, might have been to force government involvement in the setting and regulation of newspaper editorial policy.

Although this argument supports the result in Herald Co., its logic is not necessarily limited to newspapers. It is to some degree applicable to any unregulated industry which serves a public need in a noncompetitive market. Nevertheless, a limited application can be justified by reference to the constitutional commitment to, and the overwhelming political importance of, an unrestrained press.

\section{B. Herald Co. in the Mainstream of Corporate Law}

An alternate theory may be advanced, justifying the Tenth Circuit's conclusions without direct conflict with substantial corporate law precedent. The opinion, although using new language, may have only made express what has been established by implicit judicial acceptance of the assumption of public responsibilities by corporate directors. Thus the judiciary's traditional reluctance to interfere with director discretion in business decisions may be viewed as tantamount to judicial approval of corporate acceptance of public duty.

Illustrative is the Illinois appellate court's opinion in Shlensky $v$. Wrigley, ${ }^{50}$ a derivative suit brought on behalf of minority shareholders of the Chicago Cubs against the corporation's president and principal stockholder, Philip Wrigley. The plaintiffs sought damages and an order forcing Wrigley to install lights in Wrigley Field. The plaintiffs alleged that Wrigley's refusal to install lighting in the past had made home night games impossible and resulted in a loss of gate receipts. Wrigley refused to permit the Cubs to play home night games because he believed that night baseball is detrimental to the national pastime and to the neighborhood surrounding the stadium.

The plaintiff stockholders claimed Wrigley was acting upon reasons unrelated to the financial interests and welfare of the Cubs,

5095 III. App. 2d 173, 237 N.E.2d 776 (1968). See also Sylvia Martin Foundation, Inc. v. Swearingin, 260 F. Supp. 231 (S.D.N.Y. 1966). Cf. Union Pac. R.R. v, Trustees, Inc., 8 Utah 2d 101, 329 P.2d 398 (1958). 
thereby overstepping his authority as president. The court refused to consider the complaint, holding that as long as no fraud, illegality or conflict of interests was shown, it would not interfere with the internal affairs of the corporation. Thus, by refusing to interfere in the case, the court gave tacit approval at stockholder expense to Wrigley's assertion of a personally-felt social duty to "save baseball" and to protect the neighborhood around Wrigley Field.

The Tenth Circuit in Herald Co. expressly agreed with this recognition of broad discretionary powers vested in the directors:

Within the limits of their legal authority, officers and directors of a corporation, by necessity, possess a large amount of discretionary power. That power, if exercised honestly and with reason, is not subject to control by either the stockholders or the courts. ${ }^{51}$

Ultimately this position may be the basis of the court's conclusion that the directors may use corporate funds to seek what they view as socially beneficial ends.

If this analysis is correct, the court did not lay a foundation for a new view of corporate social responsibility but rather reaffirmed a recognized view of corporate discretion. The important development is the extent to which the court was willing to allow directors to exercise this discretion in a manner which admittedly sacrificed substantial profits, but which implemented an important duty to the public and employees.

\section{The Herald Co. Challenge to the Law}

If corporations are to be tapped as a resource for confronting and responding to social problems, courts must extend the limits on the valid exercise of director discretion to include the power to make decisions which advance the public interest at a marginal profit cost to the corporation. Where socially-oriented policy decisions reduce the earnings of a company, the price of its stock will not reflect the full earning potential of the corporation. ${ }^{52}$ This will make such firms ideal targets for acquisition-minded investors. To ask directors to act in a socially responsible manner but to refuse them the means by which to defend against attacks to which that responsiveness will open them is unreasonable. The law must allow directors to defend their policies. Should the stockholders disagree with the exercise of such corporate discretion, the power to remove directors remains.

This extension of corporate discretion falls sort of the imposition 
of a new general obligation, a fiduciary duty, upon corporate directors to weigh the public interest in all policy decisions. Such an obligation, if eventually imposed, must follow a more thorough examination of its legal and economic consequences and a more precise definition of standards and objective measures of social responsibility. The bold dicta of the Tenth Circuit's opinion in Herald Co. challenge attorneys, economists and courts to make just such an examination. 